\title{
Testicular Granulosa Cell Tumor
}

National Cancer Institute

\section{Source}

National Cancer Institute. Testicular Granulosa Cell Tumor. NCI Thesaurus. Code C6357.

A rare sex cord-stromal tumor that arises from the testis. It is characterized by the presence of granulosa-like cells and Call-Exner bodies. There are two variants described, the adult and the juvenile. 